\title{
THE FAMILY AND THE SCHOOL: INTERACTION IN SHAPING OF PUPILS' HUMANISTIC VALUES
}

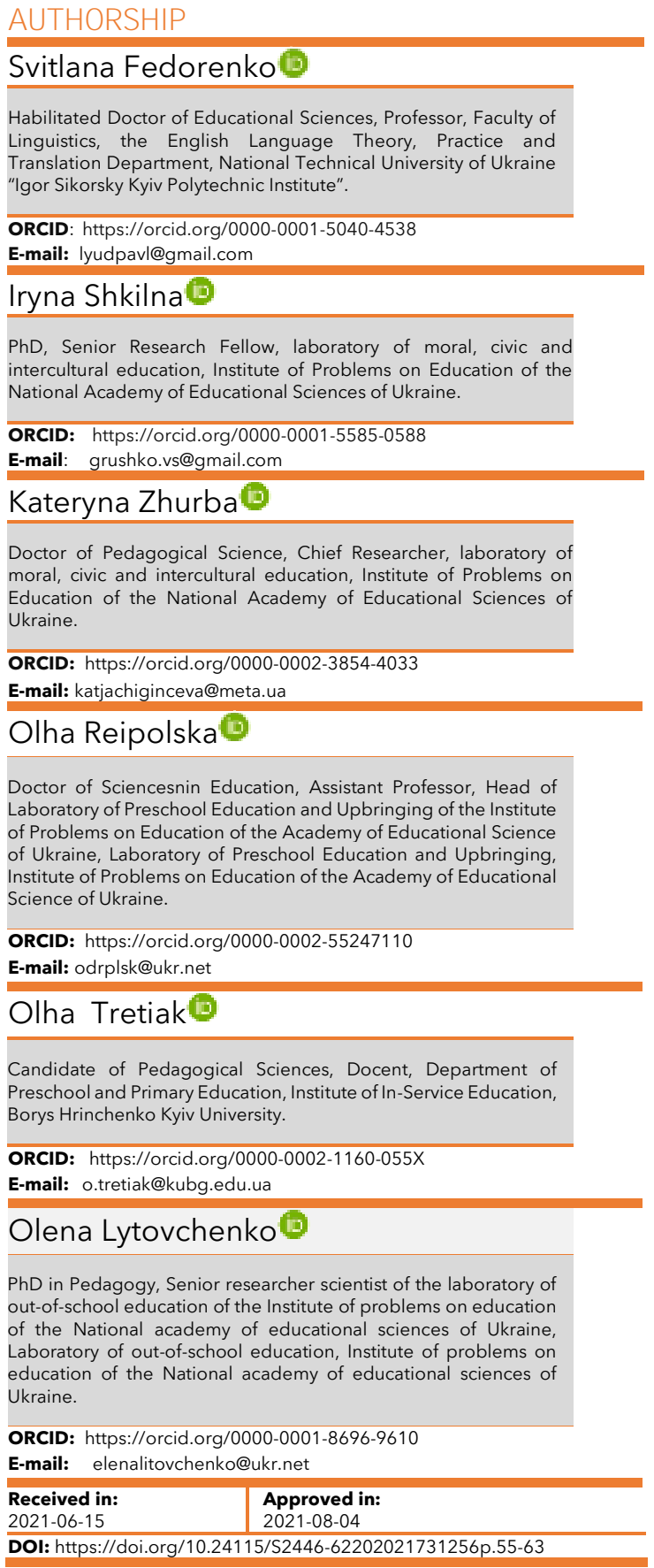

\section{INTRODUCTION}

The pedagogical process, which aims to form humanistic values, is characterized by a constant relationship between theory and practice, the body of knowledge and tasks that require practical experience and group work of all participants in the educational space: parents, teachers, students (WAY, 2016;SHIN, 2018). Understanding the importance of the influence of family, school and peers on the social development of adolescents, the formation of its humanistic values are extremely important because they are the starting point for the formation of studentcentered curricula, a set of extracurricular activities to stimulate social development. This is an extremely important task for modern pedagogical science: the organization and conduct of empirical research on the role of family and school in the formation of humanistic values of adolescents. Parents and the school should work to stimulate the integrated development of students, actualizing three areas of knowledge: cognitive, psychomotor and affective. Techniques should be developed so that teachers can stimulate all potential students to work (TAYLOR et al. 2015) and perceive the student as a person, a social being (PETERSON, NASSAJI, 2016).

A large number of studies that have been devoted to the social development of children and youth, namely the development of the ability to understand social interaction and carry out appropriate psychosocial functioning, this is the attitude to their groups, parents, adults, peers (JAVADI, TAHMASBI, 2019). In this context, the interaction of parents and the school in the formation of humanistic values is an important position and requires the search for effective ways to implement it.

Socially developed in humanistic values, the child achieves good results, which, in turn, provides job satisfaction and a competent role in the community to which they belong (DEKOVIC, JANSSENS, 1992). Deković, Janssens (1992) emphasize that the community is the basis for creating the context of social development of the individual, and communities (families, schools, peer groups) should maintain partnerships, interact in the education of a holistic and modern personality.

\section{AIMS}

In order to implement research aims to establish and assess the feasibility of interaction between family and school in influencing the formation of humanistic values of adolescents, the following tasks should be performed: 
- to establish a rating of value orientations of teenagers;

- to determine the assessment of one's own success and readiness to accept humanistic values;

- to calculate the attitude of high school students to humanistic values.

\section{LITERATURE REVIEW}

Today's school should be an institution open to creativity and innovation, always ready for change and flexible to adjust development strategies (JAYASHREE, 2017; PURANIK, 2020; VALEEVA et al. 2016). However, many works (OLSON, KROEGER, 2001; SENTHILKUMAR, KANNAPPA, 2017) criticize the modern education system for lacking the spirit of unity, sometimes inability to empathize, understand and explain. Methods are considered; fundamentally involve work on self-control, independence and adaptability of the student, the student to the learning environment, the ability to solve problems, to persevere towards the goal (WANG, 2017; SANTOS et al. 2020).

Many studies have raised the need to shift the focus of the educational system to build a model of educational partnership with parents (MALEŠ, 2004; WONG et al. 2020). This model involves changing roles between parents and teachers will help shape critical thinking and teach students to self-regulate their own educational goals. It is important to note that there are a number of studies that have confirmed that parents' educational style is related to the level of development of the child's pro-social behavior, humanistic educational attitudes (XANIDIS, BRIGNELL, 2016), follows on the social status of the individual (DAMIAN et. al. 2017). The introduction of an authoritative style creates welcoming and friendly relationships in the family, which are subsequently modeled in behavior with peers and are well received in the learning environment. Moreover, demonstration in school and at home system of punishment and threats cause difficulties (BLAŽEVIĆ, 2016). Published results of pedagogical experiments on the formation of humanistic values in higher education show that give students feel competent, teach respect for themselves, their decisions, then appear in learning achievement, and satisfaction from the results, there is assimilation of their successes both at home and in the educational institution (BULJUBAŠIĆ-KUZMANOVIĆ, 2012).

The role of parents in fostering humanistic values, the role of the family in the successful learning of the child (Steinberg, Silk, 2002) was often investigated. Open communication between everyone in the family promotes the development of children with good social skills and problem-solving skills. Warm relationships and good parent-child relationships in learning activities promote quick adjustment, socialization into the team (DARLING, STEINBERG, 1993). All of the above-mentioned studies point to the great influence that the social environment has on the schoolchild. It is the formation of humanistic values, a sense of stability and connection to family, school, and friends, all of which can be continually developed and improved.

In the future, it is necessary to work on the development and implementation of the program, which provides for the inclusion of effective forms and methods of shaping humanistic values in schoolchildren. The family and school are an important part of the material and spiritual activity of society, a product of culture, supported by the fundamentals of national mentality, and have an essential place in modern secondary education.

\section{METHODS}

The main method of the study was a pedagogical experiment. The method of questioning and observation was used for continuous monitoring of the project performance.

A pilot project was introduced to implement the research goals, which was implemented on the basis of Zaporizhzhya Academic Lyceum "Perspective" and Zaporizhzhya Lyceum № 34 (Zaporizhzhya, Ukraine). 72 high school students took part in the project, and during the academic year (2 semesters) they participated in the research program. In the framework of the program were formed curricula, materials and plan of activities for the participation of teachers, parents, lyceum students.

During the first stage, preparatory activities and a preliminary questionnaire were introduced to assess the students' own progress and readiness to perceive humanistic values. Step 1 of 
the project - the structure, components, rules of interaction of all participants are defined, active discussion of organizational aspects with students and parents takes place.

Step 2. At this stage, the educational complex involves a system of didactic materials, planned active group and project activities, a series of extracurricular activities, career guidance discussions, and work on joint measures with parents, familiarization with new educational technologies of the student's choice. In each grade, the research group constantly monitored changes in knowledge, attitudes toward humanistic values, and the influence of parents, school, and the environment. Steps are taken to better provide the methodological and vocational components of learning, the design of the project is formed and adjusted, planning takes place, the distribution of roles in particular. At this stage, the lyceum students are questioned about their attitudes and awareness of the content of humanistic values. Teachers and parents in the formation of humanistic values on an ongoing basis do this in order to determine the feasibility of introducing educational work.

Stage 3. At the final stage the changes (if any) in the evaluations of their own success, their readiness to accept humanistic values are monitored and the rating of the value orientations of the adolescents is determined. The questionnaire was introduced in order to evaluate the usefulness of such a program and to determine the level of motivation for humanistic values.

During the experiment, the research team adhered to rules of privacy and anonymity, all activities and materials agreed with the administrators of the institutions, teachers, parents and students.

Regarding the difficulties faced by the researchers on the project, these are significant time expenditures (learning river), as well as difficulties in determining the reasons for changes in respondents' evaluations, there is no opportunity to conduct qualitative in-depth research.

\section{RESULT}

The study involved 3 class lyceum students ( 72 people) between the ages of 15 and 16, who studied in 2 lyceums ( Zaporizhzhya, Ukraine) the experiment took place during the academic year 2020-2021. Five teachers were involved to the project. They taught the courses "Algebra and Geometry", "English Language" and "Physics" and were curators of the classes, responsible for educational measures and work with parents of these classes in the institutions.

The students already had a general idea of humanistic values, but they had not actively applied them in the courses before. Work with parents took place in parallel with the educational activities, trainings and master classes were held, and textbooks on the theory of humanistic education were used. The level of the success of each pupil depended on the degree of his participation in the project, the correctness and interest of the whole family and the support of the administration.

The Lyceum students and their families were introduced to a number of principles of the humanistic theory of learning, on which the teaching and learning process was built. Teaching and didactic materials, practical and psychological work were carried out based on the basic principles presented. 
Figure 1. Principles of humanistic theory of learning.

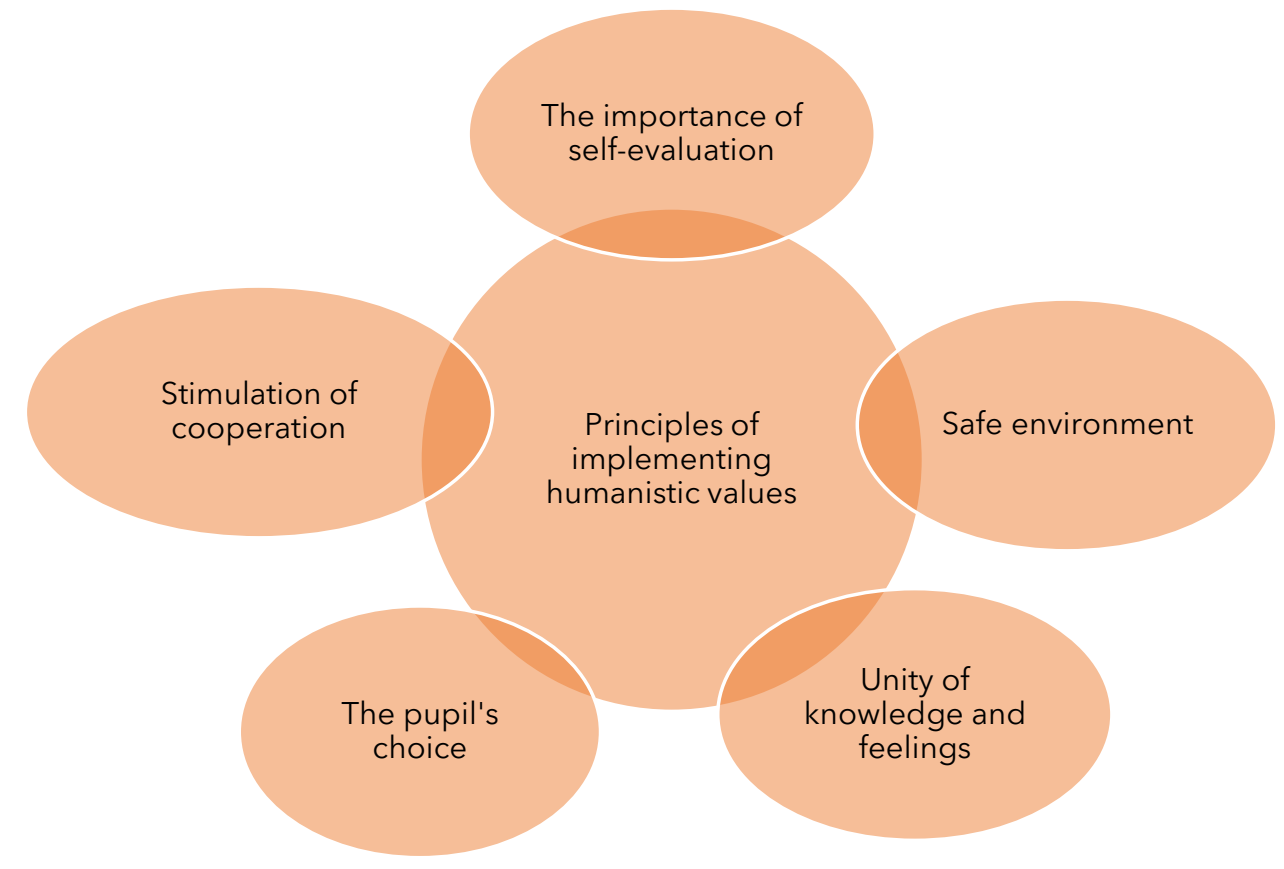

Source: Search data.

1. Pupil choice is central to the implementation of humanistic principles of learning. The interests and personality of the student should always be at the center of the learning process, so the Lyceum students are invited to take control of their own education. The pupil, together with the family, can choose the ways and types of daily work and learning goals that are aligned with future plans. Lyceum students are encouraged to focus on a certain area for a certain amount of time, the students choose for themselves. Teachers and parents help build motivation and engage the teenager in the learning process. In addition, that is assuming the student is willing to learn what they are actually interested in and what they want for the future.

2. Stimulation of group work, interaction in learning. Such measures are aimed at forming selfmotivation for learning. The effectiveness of this approach is based on a sense of involvement in the choice and therefore there is a desire to learn. Teachers on the program conducted individual work with the lyceum students and determined the circle of their hobbies and on this; they built the curriculum their content and form.

3. The importance of self-assessment. This is the best way to determine the success of learning. Moreover, followers of the humanistic theory of learning as a quite postmodernist trend do not consider evaluation to be an influential part of the formation of the humanistic values of a child, an adolescent in particular. The ability to properly assess oneself encourages one to work hard, to work in a group for one's own enjoyment, rather than being stressed and excited about the learning process.

4. The relationship of knowledge and emotion is important to the learning process (they should not be separated). This combination of affective and cognitive components leads to more effective acceptance of the material. The learning material should be shaped according to the needs and purpose of the particular student, his intellectual capacity and emotional attunement.

5. Providing a safe learning environment. Only aimed at the interests of students approach should take into account the comprehensiveness of the process, so that students can meet more of their learning needs.

In the first (preparatory) stage, teachers developed and presented the main activities to students and parents. The participants of the project gathered in the classroom of their lyceum and discussed all aspects of the future work, asked questions, determined future actions. The main components of the technology were: 
- Using the Teach learning skills policy - focusing on and supporting the development of learning skills. Lyceum students choose their own teaching methods and determine the best ways for them to learn the material.

- Providing motivation to work and succeed. Teachers chose activities that were exciting and could interest students.

- Provide a choice of topics to study, the task. The possibility of free choice in the study of material occupies a pivotal position in humanistic education.

- Constant introduction of group forms of work and study with peers. The teacher could advise in the creation of the group, the possibility of collective work, help students to observe themselves and evaluate themselves.

This stage also included the first survey of high school students, monitoring their level of commitment to humanistic values in education and their level of satisfaction with their learning in class, the lyceum.

Table 1. Assessment of one's own success and readiness to accept humanistic values

\begin{tabular}{|l|l|l|l|}
\hline $\begin{array}{l}\text { Question } \\
\begin{array}{l}\text { From time to time, I think about my own } \\
\text { purpose in life. }\end{array}\end{array}$ & $65 \%$ & $0 \%$ & $35 \%$ \\
\hline \begin{tabular}{l} 
Choosing my priorities... \\
\hline I remember my results and...
\end{tabular} & $54 \%$ & $16 \%$ & $30 \%$ \\
\hline $\begin{array}{l}\text { I talk to parents and teachers about my plans } \\
\text { and... }\end{array}$ & $22 \%$ & $10 \%$ & $48 \%$ \\
\hline
\end{tabular}

Source: Search data.

At the second stage, permanent meetings and the organization of joint activities with the lyceum students, teachers-curators, and parents were introduced. In the classroom, students are offered a number of training, research, and creative projects to do as a group, free choice of topic is provided, there is closer to the students. For the presentation of projects and entertainment activities, competitions are invited parents and all interested students of the Lyceum. The institution constantly conducted vocational orientation, excursions to industry institutions and HEls, interviews with students, constant monitoring of their orientation, and attitudes towards learning, in particular. At the final stage of the experiment, parents were presented with a form with 10 questions, which showed the typical behavior of students and the value of humanistic education in the family.

Table 2. Attitudes of lyceum students to humanistic values

\begin{tabular}{|c|c|c|c|c|}
\hline № & Question & Regularly & Sometimes & Occasionally \\
\hline 1. & The teenager has the right to vote & $25 \%$ & $10 \%$ & $12 \%$ \\
\hline 2. & $\begin{array}{l}\text { The family occupies an important place in the life } \\
\text { of the student }\end{array}$ & $16 \%$ & $31 \%$ & $9 \%$ \\
\hline 3. & Close and warm relationship with parents & $76 \%$ & $10 \%$ & $21 \%$ \\
\hline 4. & The teenager is always happy to welcome guests & $10 \%$ & $34 \%$ & $12 \%$ \\
\hline 5. & The teenager takes care of the younger ones & $21 \%$ & $19 \%$ & $18 \%$ \\
\hline 6. & $\begin{array}{l}\text { The teenager always shares his career intentions } \\
\text { with his parents }\end{array}$ & $71 \%$ & $9 \%$ & $20 \%$ \\
\hline 7. & The student is happy to perform creative tasks & $65 \%$ & $27 \%$ & $8 \%$ \\
\hline 8. & $\begin{array}{l}\text { The teenager loves holidays, joint family and } \\
\text { school activities }\end{array}$ & $89 \%$ & $3 \%$ & $8 \%$ \\
\hline 9. & The teenager does his homework & $30 \%$ & $27 \%$ & $35 \%$ \\
\hline 10. & Adolescents respect teachers and value learning & $66 \%$ & $32 \%$ & $12 \%$ \\
\hline
\end{tabular}

Source: Search data.

From the data, we can conclude that the lyceum students rely on their families and teachers, trust them, and adhere to family obligations and activities. Based on the ascertaining experiment and theoretical understanding of the problem the work on the development of the program to strengthen the influence of the school and parents on the formation of humanistic values of adolescents in the educational and extracurricular work began. At the final stage of the program, the degree of formation of humanistic values is measured on the ground survey 
of the lyceum students-participants of the experiment in order to identify changes in value orientations. Pupils are offered to define a rating of the most significant, in their opinion, values.

Table 3. Rating of value orientations of adolescents.

\begin{tabular}{l|l}
\hline \multicolumn{1}{c}{ Value } & Rating \\
\hline 1.Universal knowledge for a career & $80 \%$ \\
\hline 2.freedom of choice & $78 \%$ \\
\hline 3. Good relationship with friends & $67 \%$ \\
\hline 4. Harmonious family relationships & $65 \%$ \\
\hline 5.Positive interaction in the lyceum & $57 \%$ \\
\hline 6. Ensuring a good position in the group & $56 \%$ \\
\hline $\begin{array}{l}\text { 7.Effective communication in personal contacts (usefulness, loyalty, honesty, responsibility, true } \\
\text { sympathy, ability to forgive). }\end{array}$ & $54 \%$ \\
\hline
\end{tabular}

Source: Search data.

Continuous monitoring in the form of a survey of lyceum students' attitudes to humanistic values as part of the cognitive component and the impact on their formation of teachers and families showed some evolutionary changes. Conclusions on the creative and cognitive components showed that the level of theoretical knowledge about the principles and composition of humanistic values has changed for the better. The level of knowledge of such concepts as "freedom of choice", "work for the benefit of the group", "self-esteem" show that awareness of the basic concepts of humanistic education is high, and the presence in the ranking of priorities such concepts as family, friends, school, loyalty, usefulness etc. show the movement towards humanistic values. Lyceum students' answers to the questionnaire became more specific and meaningful. This makes it easier to adapt to learning activities, determine your future path, range of interests, and correctly assess your capabilities.

Table 4. Assessment of one's own success and readiness to accept humanistic values

\begin{tabular}{l|l|l|l}
\hline Question & Satisfied & I do not know & Disappointed \\
\hline $\begin{array}{l}\text { From time to time, I think about my own } \\
\text { purpose in life. }\end{array}$ & $78 \%$ & $0 \%$ & $22 \%$ \\
\hline $\begin{array}{l}\text { Choosing my priorities... } \\
\text { I remember my results and... }\end{array}$ & $60 \%$ & $12 \%$ & $28 \%$ \\
\hline $\begin{array}{l}\text { I talk to parents and teachers about my plans } \\
\text { and.... }\end{array}$ & $30 \%$ & $10 \%$ & $28 \%$ \\
\hline
\end{tabular}

Source: Search data.

Lyceum students formed an emotional and positive image of the school and a positive attitude to humanistic values. Satisfaction with their own learning, interaction at school, with friends, parents increased by an average of $9 \%$. As can be seen from the results, the project had a positive impact on the psychological climate in classes and families (increased satisfaction by an average of $10 \%$ ), all components in the survey increased the number of positive responses.

\section{DISCUSSION}

The pedagogical branch has a small number of experimental studies concerning the application of empirical research on the role of family and school in the formation of humanistic values in children, adolescents, and young people. A number of studies (ZAKIROVA et. al., 2016; BLAŽEVIĆ, 2016) have considered the influence of family values on the style and purpose of students' learning in higher education. In such studies, in parallel with the theoretical rationale, a number of methods for ensuring the development of higher education were tested. The system of values of adolescents in the form of a universal scale of basic humanistic values (tolerance, understanding, protection of welfare) were presented, but great importance is given to freedom of choice, independence and safety (ZAKIROVA et. al., 2016). The results of our study are congruent, as teenage respondents ranked freedom of choice (78\%) and good relationships at school, with friends, and with parents as the most important humanistic educational principles (65\% on average).

Other researchers (BLAŽEVIĆ, 2016; WONG et. al. 2021) in defining the role of modern school, family and groups in the formation and development of social skills of the child relied on the thesis that school, friends and family is a community in which students grow, feeling success and positive emotions, good results. School should be a place where the child can show their skills, skills, non-violent resolution of conflicts, and learning should be creative and interesting, 
develop teamwork skills and be tolerant, use the acquired experience of communication successful building in family and with friends (BULJUBAŠIIĆ-KUZMANOVIĆ, 2012).

In fact, the results of the experiment showed that school can be beneficial for the social adaptation of adolescents in society and together with the family affects the formation of humanistic values. Overall, at the end of the experiment, $78 \%$ of adolescents think about their own goal and are satisfied with it, and $60 \%$ are satisfied with their choice of career priorities in life. Work on the formation of humanistic values is comprehensive, as indicated in several studies (SYNORUB, MEDYNSKA, 2019; ZAKIROVA et. al., 2016; ZHERNOVA, 2018) the role of educating an active citizen, positive attitude and continuous volunteer activities, is also effective in educational practice of higher education (IVANOVA, et. al. 2020).

In the project, students who participated in exhibition activities, engaged in volunteerism had an active citizenship better learning (on average 6\%) and in the future had a career growth, according to their plans. In fact, our study showed that active interaction between school and parents in the formation of humanistic values is useful for the social development of students, as well as similar practices have a positive impact on students. It is also worth remembering that further development of projects to reform the school itself is needed, it is worth working on continuous support of students' aspirations, to develop skills of empathy and sympathy. To create an environment where the pupil feels accepted, understood, respected and counted. Further research is needed to develop models to encourage the development of realistic expectations of students, as well as to correct teenagers' attitudes to failures in learning and communication in particular.

\section{CONCLUSION}

The research project has shown that the use of the program built constant interaction between parents and teachers has a positive impact on the formulation of humanistic values in adolescents. This conclusion is confirmed by the results of constant monitoring of attitudes and evaluations by the Lyceum students participating in the program. At the end of the experiment we got positive results from the family-teacher-student interaction ( $78 \%$ have a goal and are satisfied with it, $60 \%$ have their own priorities and are satisfied with them), this is $10 \%$ more than was presented to the survey at the beginning of the experiment. This conclusion is confirmed by the results of surveys, rankings, and monitoring of positive changes in the Lyceum students' assessment of the formation of knowledge of humanistic values.

The efficiency of influence of their formation lies in constant interaction of parents and teachers, an active position of all participants of educational process. Educational and extracurricular work should be based on the main characteristics of the concept of humanistic learning and take into account the age aspects of the value orientations of adolescents. Thus, we can conclude that the positive influence of the family and teachers on the formation of the adolescent's humanistic values is an indicator of the stable beginnings in the social sphere of relationships; it is really the primary socialization in the society.

It is necessary to continue to work on the modernization of the educational system, the development of pedagogical technologies where the emphasis would be placed on the involvement of family and school in the formation of humanistic values of adolescents.

\section{REFERENCES}

BLAŽEVIĆ, I. Family, Peer and School Influence on Children's Social Development World Journal of Education, 2016, vol. 6, no. 2, 42-49.Available at: http://doi:10.5430/wje.v6n2p42. Acess: May 28, 2021.

BULJUBAŠIĆ-KUZMANOVIĆ, V. Škola kao zajednica odrastanja. Pedagogijska istraživanja, 2012, vol. 9(1-2), 43-57. Available at: https://hrcak.srce.hr/file/167719. Acess: May 28, 2021.

DAMIAN, S. I. et al. The Role of Educational Measures for Juvenile Offenders in Forensic Psychiatry. Revista Românească pentru Educaţie Multidimensională, 2017, 9(3), 140-155. Available at: https://doi:10.18662/rrem/2017.0903.09. Acess: May 28, 2021. 
DARLING, N.; STEINBERG, L. Parenting style as context: An integrative model. Psychological Bulletin, 1993, vol. 113(3), 487-496. Available at: http://dx.doi.org/10.1037/0033-

2909.113.3.487. Acess: May 28, 2021.

DEKOVIĆ, M. \& JANSSENS, J. Parent's Child-Rearing Style and Child's Sociometric Status. Developmental Psychology, 1992, vol. 28(5), 925-932. Available at: http://dx.doi.org/10.1037/0012-1649.28.5.925. Acess: May 28, 2021.

IVANOVA, I.; MOSENKIS, I. \& STROKAL, O. Modern media pedagogy: Ways of forming public journalism in Ukraine. Asia Life Sciences, 2020, 22, Issue 2, 357-370

JAVADI, Y.; TAHMASBI, M. Application of Humanism Teaching Theory and Humanistic Approach to Education in Course-books. Theory and Practice in Language Studies, 2019, vol. 10(1), 40-48. Available at:10.17507/tpls.1001.06. Acess: May 28, 2021.

JAYASHREE, R. A Study on Innovative Teaching Learning Methods for Undergraduate Students. International Journal of Humanities and Social Science Invention, 2017, vol. 6(11), 32-34. Available at: http://www.ijhssi.org/papers/v6(11)/Version-2/E0611023234.pdf. Acess: May 28, 2021.

MALEŠ, D. Roditelji i učitelji zajedno. U: Vrgoč. H. (Ed.), Strategija odgojnog rada razrednika (zbornik radova). Zagreb: HPKZ, 2004, 26-38.

OLSON, C. L.; KROEGER, K. R. Global competency and intercultural sensitivity. Journal of Studies in International Education, 2001, vol. 5, 116-137. Available at: https://doi.org/10.1177/102831530152003. Acess: May 28, 2021.

PETERSON, C. AND NASSAJI, H. Project-based learning through the eyes of teachers and students in the adult ESL classroom. The Canadian Modern Language Review, 2016, vol. 72(1), 13-39.

PURANIK, S. Innovative teaching methods in higher education. BSSS Journal of Education 2020, vol. IX, issue I, 67-75.

SANTOS, I.; BARRETO, D.; SOARES, C. Formative assessment in the classroom: the dialogue between teachers and students. Journal of Research and Knowledge Spreading, 2020, vol. $1(1), 1-14$.

SENTHILKUMAR,V.; KANNAPPA, R. Impact of Innovative Teaching and Learning Methodologies for Higher Educational Institutions with reference to Trichirappalli District. IOSR Journal of Business and Management (IOSR-JBM), 2017, vol. 19(7), 88-92. doi: 10.9790/487X-1907028892

STEINBERG, L.; SILK, J. Parenting adolescents. U: Bornstein M. H. (Ed.), Handbook of parenting: Vol. 1: Children and parenting. Mahwah, NJ: Lawrence Erlbaum Associates, 2002, $103-133$.

SYNORUB, H.; MEDYNSKA, O. Development of information culture of students of humanitarian specialities. Information Technologies and Learning Tools. 2019, 2019, Vol 72 (4), 152-167. Available at: https://doi.org/10.33407/itlt.v72i4.2922. . Acess: May 28, 2021.

TAYLOR, K. et al. Parent training and adolescent social functioning: a brief report. Journal of Child and Family Studies, 2015, vol. 24 (10), 3030-3037. Available at: http://doi:10.1007/s10826-014-0106-2. . Acess: May 28, 2021.

VALEEVA, R.; KOROLYEVA, N.; SAKHAPOVA, F. Case-study of the high school student's family values formation International Journal of Environmental \& Science Education, 2016, vol. 11(7), 1641-1649. Available at: http://doi:10.12973/ijese.2016.369a. . Acess: May 28, 2021. 
WANG, J. Cloud Computing Technologies in Writing Class: Factors Influencing Students Learning Experience. Turkish Online Journal of Distance Education, 2017, vol. 18, 197-197.

WONG, H.Y.et al. Relationships between severity of internet gaming disorder, severity of problematic social media use, sleep quality and psychological distress. International journal of environmental research and public health, 2020, 17 (6) (2020), 1879. Available at: http://doi:10.3390/ijerph17061879. . Acess: May 28, 2021.

XANIDIS, N.; BRIGNELL, C. The association between the use of social network sites, sleep quality and cognitive function during the day. Available at: Computers in Human Behavior ,2016, vol. 55, 121-126. Available at: https://doi.org/10.1016/j.chb.2015.09.004. Acess: May $28,2021$.

ZAKIROVA, V.; MASALIMOVA, A.; NIKOGHOSYAN, M. The Contents, Forms and Methods of Family Upbringing Studying Based on the Differentiated Approach. Mathematics Education, 2016, vol. 11(1), 181-190. Available at: http://doi:10.12973/iser.2016.21017a. . Acess: May $28,2021$.

ZHERNOVA, A. Information and Communication Technologies in Higher Education: Toward the Preparedness of the Subjects of Education for Innovation. Scientific Research in Social and Political Psychology, 2018, vol. 33, 172-179.

The family and the school: interaction in shaping of pupils' humanistic values

A família e a escola: interação na formação dos valores humanísticos dos alunos

La familia y la escuela: interacción en la formación de los valores humanísticos de los alumnos

\section{Resumo}

O objetivo do estudo é a fundamentação teórica da influência da escola e da família na formação de valores humanísticos nos adolescentes, bem como estabelecer a viabilidade de introduzir formas e métodos para garantir a interação efetiva entre todos os participantes no processo educacional, o desenvolvimento do ensino médio na formação de valores humanísticos. 72 estudantes do ensino médio, seus pais e professores de Zaporizhzhya (Ucrânia) participaram do experimento. Para estudar as formas de formação de valores humanísticos na interação entre escola e família, foi aplicado o método de experiência pedagógica, a visão dos alunos sobre valores humanísticos e a avaliação dos entrevistados sobre sua influência na aprendizagem e no sucesso foram investigadas por meio de questionários, a análise estatística dos resultados empíricos foi realizada com a ajuda de métodos padrão de estatística matemática.

Palavras-chave: Valores familiares. Tradições. Relacionamentos familiares. Professores humanistas. Educadores humanistas.

\section{Abstract}

The aim of the study is the theoretical substantiation of the influence of school and family on the formation of humanistic values in adolescents, as well as establishing the feasibility of introducing forms and methods to ensure effective interaction between all participants in the educational process, the development of secondary education in the formation of humanistic values. 72 high school students, their parents and teachers from Zaporizhzhya (Ukraine) took part in the experiment. To study the ways of forming humanistic values in the interaction between school and family, the method of pedagogical experiment was applied, the students' views on humanistic values and the respondents' evaluation of their influence on learning and success were investigated by means of questionnaires, statistical analysis of empirical results was conducted with the help of standard methods of mathematical statistics.

Keywords: Family values. Traditions. Family relationships. Humanistic teachers. Humanistic educators.

\section{Resumen}

El objetivo del estudio es la fundamentación teórica de la influencia de la escuela y la familia en la formación de valores humanísticos en adolescentes, así como establecer la viabilidad de introducir formas y métodos para asegurar la interacción efectiva entre todos los participantes en el proceso educativo, el desarrollo de la educación secundaria en la formación de valores humanísticos. 72 estudiantes de secundaria, sus padres y profesores de Zaporizhzhya (Ucrania) participaron en el experimento. Para estudiar las formas de formación de valores humanísticos en la interacción entre la escuela y la familia, se aplicó el método de experimentación pedagógica, se investigaron las opiniones de los estudiantes sobre los valores humanísticos y la evaluación de los encuestados de su influencia en el aprendizaje y el éxito por medio de cuestionarios, se realizó un análisis estadístico de los resultados empíricos con la ayuda de métodos estándar de estadística matemática.

Palabras-clave: Valores familiares. Tradiciones. Relaciones familiares. Maestros humanistas. Educadores humanistas. 